\title{
KETEPATAN DIAGNOSA KEPERAWATAN DALAM ASUHAN KEPERAWATAN
}

\author{
Fitri Rahmadani Siregar
}

danisiregar1001@gmail.com

\section{Latar Belakang}

Diagnosa merupakan salah satu tahap dalam proses keperawatan, yang dilakukan setelah pengkajian. Diagnosa keperawatan adalah proses menganalisis data yang didapatkan melalui proses pengkajian untuk menegakkan diagnosa. Sebelum merumuskan diagnosa, perawat memiliki tanggung jawab untuk mengenal atau mengidentifikasi masalah kesehatan klien. Untuk mengidentifikasi kebutuhan klien, perawat harus lebih dulu menentukan apakah masalah kesehatan pasien tersebut aktual atau potensial. Masalah kesehatan aktual adalah masalah ynag dialami atau dirasakan pasien, seperti gangguan pola tidur yang berhubungan dengan lingkungan yang bising. Sedangkan masalah kesehatan potensial atau beresiko mewaspadakan perawat pada pentingnya intervensi pencegahan (Gordon, 1994 di Potter \& Perry, 2005).

Keperawatan adalah suatu bentuk pelayanan profesional yang merupakan bagian integral dari pelayanan kesehatan berdasarkan ilmu dan kiat keperawatan berbentuk pelayanan biologis, psikologis, sosiologis dan spiritual yang komprehensif/holistik yang ditujukkan kepada individu, keluarga dan masyarakat baik dalam keadaan sehat atau sakit yang mencakup seluruh proses kehidupan manusia yang mengacu pada standar profesional keperawatan dan menggunakan etika keperawatan sebagai tuntutan utama (Nursalam, 2011).

Penegakan diagnosis keperawatan sebagai salah satu komponen standar asuhan keperawatan perlu dilaksanakan dengan baik sebagaimana yang diamanahkan dalam undang-undang No.38 tahun 2014 tantang keperawatan pada pasal 30 bahwa dalam menjalankan tugas sebagai pemberi asuhan keperawatan, perawat berwenang menetapkan diagnosis keperawatan. Hal ini menegaskan wewenang perawat sebagai penegak diagnosis yang harus memiliki kemampuan diagnosis yang baik sebagai dasar mengembangkan rencana intervensi keperawatan dalam rangka mencapai peningkatan, pencegahan dan penyembuhan serta pemulihan kesehatan klien. 
Diagnosis keperawatan merupakan penilaian klinis terhadap pengalaman/respon individu, keluarga, atau komunitas pada masalah kesehatan/ risiko masalah kesehatan atau pada proses kehidupan. Diganosa keperawatan merupakan bagian vital dalam menentukan asuhan keperawatan yang sesuai untuk membantu klien mencapai kesehatan yang optimal.

\section{Metode}

Metode yang digunakan dalam penulisan ini adalah metode kualitatif yang mana mengumpulkan sebanyak-banyaknya data untuk dianalisis. Tulisan ini didasarkan dengan menganalisis berbagai karya penelitian yang berfokus pada "Ketepatan Diagnosa Keperwatan Dalam Asuhan Keperawatan". Adapun tinjauan literature yang digunakan seperti buku, jurnal print maupun jurnal online dan e-book setiap referensi 10 tahun terakhir yang sesuai dengan judul penulisan. Metode dari penulisan ini dilakukan untuk menjelaskan bagaimana menentukan diagnosa keperawatan dalam asuhan keperawatan melalui analisa materi yang dikumpulkan dari sumber jurnal atau buku. Penulisan ini dilakukan menggunakan metode kajian bebas terhadap pokok bahasan yang dikumpulkan dari beberapa sumber yang berkaitan dengan pokok bahasan.

\section{Hasil}

Hasil dari pengkajian menggunakan metode penulisan kualitatif diharapkan dapat menghasilkan suatu pembelajaran yaitu dapat mengetahui pentingnya ketepatan diagnose keperawatan dalam memberikan asuhan keperawatan kepada pasien di rumah sakit melalui pengumpulan data berdasarkan buku teks, jurnal atau karya tulis ilmiah. Diharapkan juga agar perawat mengetahui hal-hal terkait diagnosa keperawatan serta pengambilan keputusan.

Dalam tahap diagnosa, perawat berperan secara independen, artinya perawat dapat merumuskan sendiri diagnosanya, bertanggung jawab terhadap diagnosa yang dirumuskan, membedakan peran perawat dengan peran dokter, serta menunjukkan bahwa asuhan keperawatan tersebut bermutu, mempunyai kualitas, dan atas dasar pendidikan perawat.

Perawat sebagai tenaga kesehatan yang bertugas untuk memenuhi kebutuhan dasar klien secara holistic memiliki tanggung jawab untuk membantu pemenuhan kebutuhan oksigen klien yang tidak adekuat.Dalam tindakannya, seorang perawat sebelum memberikan asuhan keperawatanharus melakukan metode keperawatan berupa pengkajian, diagnosis keperawatan, intervensi, dan evaluasi. 
TerdapatTerdapat 3 komponen diagnosa keperawatan yaitu problem, etiologic dan symptom. Problem merupakan alasan dari pemberian asuhan keperawatan, dimana keadaan yang menyimpang dari keadaan normal yang seharusnya tidak terjadi. Etiologic factor penyebab terjadinya penyimpangan status normal menjadi suatu masalah yang harus diatasi dan symptom yang merupakan kumpulan komponen data subyektif dan obyektif hasil dari pengkajian keperawatan.

Proses keperawatan merupakan suatu sistem yang disusun secara sistematis dalam pemberian asuhan keperawatan. Dalam proses keperawatan, diagnosa merupakan tahap kedua setelah pengkajian. Perawat bertanggung jawab untuk merumuskan diagnosa dengan menggunakan data-data yang terkumpul selama proses pengkajian. Diagnosa merupakan dasar untuk menentukan intervensi keperawatan yang tepat dan berkulitas. Oleh karena itu, diagnosa keperawatan yang dirumuskan atau ditegakkan oleh perawat harus tepat.

\section{Pembahasan}

Keperawatan merupakan suatu bentuk pelayanan profesional bersifat humanistik, menggunakan pendekatan holistik, dilakukan berdasarkan ilmu dan kiat keperawatan, berorientasi kepada asuhan keperawatan yang benar atau rasional (Nursalam, 2007).

Diagnosa keperawatan sejahtera telah didefinisikan dalam berbagai pustaka. NANDA (1994) mendefinisikan diagnosa keperawatan sejahtera sebagai suatu diagnosa yang menjelaskan respons manusia terhadap tingkat kesejahteraan individu, keluarga, atau komunitas yang memiliki potensi untuk meningkat pada kondisi yang lebih tinggi. Sedangkan Carpenito (1995) menyatakan bahwa diagnosa kesejahteraan adalah satu bagian pernyataan yang hanya meliputi satu label di mana klien menginginkan tingkat fungsi yang lebih tinggi. Pada dasarnya menurut Stolte, Carpenito mengusulkan bahwa diagnosa kesejahteraan hanya digunakan pada kasus yang berfokus pada perbaikan fungsi dan tujuannya adalah kemajuan dari satu tingkat kesejahteraan ke tingkat kesejahteraan yang lebih tinggi.

Proses asuhan keperawatan merupakan tugas dan kewajiban seorang perawat dari pasien datang sampai pasien pulang, dimulai dengan pengkajian secara menyeluruh, kemudian menegakkan diagnosa keperawatan dari data pengkajian tersebut, serta melaksanakan intervensi, implementasi dan evaluasi keefektifan diagnosa awal yang sudah ditegakkan (Nursalam, 2007). Pelaksanaan asuhan keperawatan profesional diwujudkan dengan menerapkan model praktek keperawatan profesional (MPKP) disetiap ruangan. Menurut 
Ratna Sitorus (2006 dikutip Nursalam 2007), MPKP adalah suatu sistem (struktur, proses dan nilai-nilai profesional), yang memfasilitasi perawat profesional, mengatur pemberian asuhan keperawatan termasuk lingkungan tempat asuhan keperawatan tersebut.

Proses keperawatan adalah kerangka kerja untuk memberikan pelayanan keperawatan yang profesional dan berkualitas (Debora, 2013). Proses keperawatan adalah metode pengorganisasian yang sistematis dalam melakukan asuhan keperawatan pada individu, kelompok, dan masyarakat yang berfokus pada identifikasi dan pemecahan masalah dari respons pasien terhadap penyakitnya (Wartonah-Tarwoto, 2004 ).

Tahap-tahap dalam proses keperawatan adalah pengkajian, diagnosis keperawatan, perencanaan, pelaksanaan, dan evaluasi. Diagnosis keperawatan adalah suatu bagian integral dari proses keperawatan. Diagnosis keperawatan ditetapkan berdasarkan analisis dan interprestasi data yang diperoleh dari pengkajian keperawatan klien. Diagnosis keperawatan memberikan gambaran tentang masalah atau status kesehatan klien yang nyata (aktual) dan kemungkinan akan terjadi, dimana pemecahnya dapat dilakukan dalam batas wewenang perawat (Nurjannah,2010).

Profesi perawat menggunakan proses keperawatan (nursing process) sebagai kerangka pikir dan kerangka kerja dalam merawat pasien. Keperawatan sebagai proses, diperkenalkan sejak tahun 1955 oleh Hall dan pada tahun 2004 proses keperawatan (nursing process) ditetapkan sebagai series of steps oleh ANA (American Nursing Association) (Wilkinson, 2007), yang terdiri dari assesment (pengkajian), diagnosis (penetapan diagnosis), planning outcomes (perencanaan hasil), planning intervention (perencanaan intervensi), implementation (implementasi) dan evaluation (evaluasi).

Pada prakteknya kegiatan proses keperawatan di atas tidaklah selalu berurutan tetapi bisa dikerjakan pada waktu bersamaan/tumpang tindih (overlapping). Salah satu kegiatan yang penting dalam proses keperawatan adalah pengkajian keperawatan. Pengkajian keperawatan ini sangat penting karena dari pengkajian keperawatan maka perawat akan mampu menentukan apa masalah keperawatan/diganosa keperawatan dan masalah kolaboratif/diagnosis potensial komplikasi yang dialami oleh pasien dan membuat perencanaan dalam merawat pasien.

Pengalaman menunjukkan bahwa sering sekali perawat kesulitan dalam menentukan diagnosis keperawatan spesifik yang dialami oleh pasien.Hal ini mungkin karena pengkajian 
keperawatan yang tidak terstruktur dengan baik.Pengalaman menunjukkan bahwa pengkajian yang dilakukan oleh perawat tidak mempunyai urutan yang runut dan terkait dengan diagnosis keperawatan.Sering terjadi perawat mempunyai data tertentu tetapi kebingungan untuk menentukan data tersebut mendukung diagnosis keperawatan yang mana. Atau sebaliknya perawat mempunyai prediksi pasien mempunyai diagnosis tertentu tetapi tidak tahu data apa yang perlu dikaji untuk mendukung diagnosis tersebut muncul (Nurjannah, 2010).

Proses mengkaji dan mendiagnosis merupakan kegiatan yang sangat penting karena menentukan keberhasilan keperawatan. Dalam merumuskan diagnosis keperawatan menurut Wilkinson (2007) terdapat beberapa kegiatan yang dilakukan dalam mendiagnosis keperawatan adalah interpretasi dari data yang ada, kemudian melakukan verifikasi dengan pasien, menentukan label diagnosis keperawatan dan menuliskan diagnosis keperawatan.

Penelitian tentang pengkajian dan diagnosa menunjukkan bahwa 50\% lembar pengkajian keperawatan tidak terisi dengan lengkap. Tidak lengkapnya pengkajian keperawatan akan berdampak pada perumusan diagnosa keperawatan. Diagnosa keperawatan dapat tersusun dengan baik ketika data mayor dan data minor dalam sebuah diagnosa ditemukan dalam hasil pengkajian.

Hasil observasi di rumah sakit bahwa untuk jumlah diagnosa keperawatan yang muncul pada satu orang pasien rata-rata satu jenis diagnosa keperawatan saja, padahal diagnosa keperawatan bisa ditegakkan berdasarkan respon pasien. Diagnosa keperawatan tunggal tersebut, bisa jadi dikarenakan pengkajian yang kurang lengkap, atau bisa dikarenakan ketidaktahuan perawat dalam menentukan diagnosa lain yang sesuai. Pada sisi lain pada diagnosa keperawatan, ditemukan adanya pernyataan nama diagnosa yang berbeda, meskipun respon masalah pasien sebenarnya sama. Jadi disini tidak ada keseragaman bahasa dalam nama diagnosa keperawatan. Sehingga seringnya diagnosa itu ditemukan menjadi hal yang terpenting dalam keperawatan. Perawat dapat mempersiapkan sumber daya untuk mengatasi diagnosa keperawatan tersebut. Rumah sakit juga akan menyiapkan kebutuhan sumber daya yang diperlukan untuk kepentingan diagnosa tersebut.

Perawat sebagai ujung tombak dalam pelayanan di rumah sakit, mempunyai tugas memberikan asuhan keperawatan antara lain mengkaji kebutuhan pasien, merencanakan tindakan keperawatan, melaksanakan rencana tindakan, mengevaluasi hasil asuhan keperawatan, mendokumentasikan asuhan keperawatan dan berperan serta dalam melakukan 
penyuluhan. Perawat sebagai salah satu profesi baik dari segi jumlah maupun segi kontak dengan pasien memiliki waktu yang lebih lama dibandingkan dengan profesi lain, maka perannya dalam meningkatkan kualitas pelayanan khususnya dalam bidang keperawatan sangat menentukan (Mubarak, 2009).

Standar kinerja perawat dapat dilakukan dengan menilai berbagai hal, antara lain kecepatan dalam bekerja, tingkat kemandirian, perilaku selama bekerja, kehadiran/pemanfaatan waktu, hubungan dengan staf lain, ketrampilan dalam bekerja, pengetahuan yang dimiliki, keabsahan pekerjaan yang dilakukan. Menurut Mc.Closkey and Grace (1990), standar asuhan keperawatan adalah alat ukur kualitas asuhan keperawatan yang berfungsi sebagai pedoman atau lolok ukur dalam pelaksanaan praktek pelayanan keperawatan.

\section{Penutup}

Untuk dapat menyembuhkan atau meningkatkan taraf kesehatan pasien, diagnosa yang ditetapkan tentu akan sangat berdampak. Saat ini perawat perlu mengangkat atau menetapkan diagnosa keperawatan yang berorientasi pada upaya tercapainya intervensi keperawatan yang berkualitas. Diagnosis keperawatan juga harus ditingkatkan lagi didalam pelayanan rumah sakit dan fasilitas kesehatan lainnya agar seragam, akurat, dan tidak ambigu. Penegakan diagnosis keperawatan sebagai salah satu komponen standar asuhan keperawatan perlu dilaksanakan dengan baik sebagaimana yang diamanahkan dalam undang-undang No.38 tahun 2014 tantang keperawatan pada pasal 30 bahwa dalam menjalankan tugas sebagai pemberi asuhan keperawatan, perawat berwenang menetapkan diagnosis keperawatan. Perawat sebagai penegak diagnosis yang harus memiliki kemampuan diagnosis yang baik sebagai dasar mengembangkan rencana intervesnsi keperawatan dalam mencapai peningkatan, pencegahan, penyembuhan dan pemulihan kesehatan klien.

\section{Referensi}

Apriyani, H. (2015). Identifikasi Diagnosis Keperawatan Pada Pasien Di Ruang Paru Sebuah Rumah Sakit. Jurnal Keperawatan, 11(1).

Budiono. (2016). Konsep Dasar Keperawatan. Jakarta Selatan : Kementrian Kesehatan Republik Indonesia.

Hidayah, \& Nur. (2014). Manajemen Model Asuhan Keperawatan Profesional (MAKP) Tim Dalam Peningkatan Kepuasan Pasien Di Rumah Sakit. Jurnal Kesehatan, 1(2), 410- 426. 
Kodim, Y. (2015). Konsep Dasar Keperawatan. Jakarta: TIM.

Nogo, A. (2014). Kinerja Perawat Dalam Penerapan Standar Asuhan Keperawatan Di Rumah Sakit Umum Daerah Naibonat Kabupaten Kupang. Jurnal Penelitian, 18(1), 62-66.

Novieastari, E. (2013). Diagnosis Keperawatan Sejahtera. Jurnal Keperawatan Indonesia, 7(2), 77-88.

Rofi'i, M., Warsito, B. E., Santoso, A. \& Ulliya, S. (2018). Diagnosa Keperawatan Yang Sering Ditegakkan Perawat Pada Pasien Tuberkulosis Paru Di Rumah Sakit. Jurnal Kepemimpinan dan Manajemen Keperawatan, 1(2), 1-8.

Simamora, R. H., Bukit, E., Purba, J. M., \& Siahaan, J. (2017). Penguatan kinerja perawat dalam pemberian asuhan keperawatan melalui pelatihan ronde keperawatan di rumah sakit royal prima medan. Jurnal pengabdian kepada masyarakat, 23(2), 300-304.

Simamora, R. H. (2019). Socialization of Information Technology Utilization and Knowledge of Information System Effectiveness at Hospital Nurses in Medan, North Sumatra. Editorial Preface From the Desk of Managing Editor..., 10(9).

Wulandini, P., Krianto, T. \& Priwahyuni, Y. (2016). Faktor-Faktor Yang Berhubungan Dengan Pendokumentasian Asuhan Keperawatan Di Rumah Sakit Jiwa. Jurnal Keperawatan, 12(2), 131-142.

Wulansari, P. \& Apriyani, H. (2016). Diagnosis Keperawatan Pada Pasien Dengan Gangguan Pencernaan. Jurnal Keperawatan, 12(1).

Yanti, R. I. \& Warsito, B. E. (2013). Hubungan Karakteristik Perawat, Motivasi, Dan Supervisi Dengan Kualitas Dokumentasi Proses Asuhan Keperawatan. Jurnal Managemen Keperawatan, 1(2), 107-114. 